\title{
TRAINING NEED FOR BUSINESS CREATION IN AUTOMATION FiELD
}

\author{
IZVERCIANU, M.; MOCAN, M. \& POPA, H.
}

Abstract: Human Resources training regarding the entrepreneurship must start in universities and continue with training over the entire professional life. The purpose of our research is to detect the knowledge gaps of the undergraduate IT students in technical Universities in the area of business creation, during their university education. The research methodologies were: phenomenological group analysis and questionnaires.

The target group was formed of senior students in automation, Master's degree students, and graduates from 20 SME's This research allows the outlining of a profile in business creation area for students with background in automation field.

Key words: Need, human resources, training, students, graduates
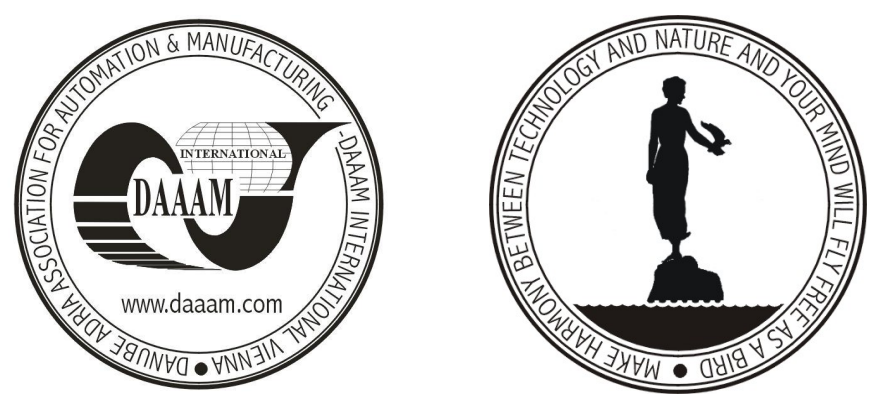

Authors' data: Prof. Dr. Eng. Izvercianu, M[onica]; Ass. Prof. Dr. Mocan, M[arian]; Prof. Dipl. Eng. Dr. Popa, H[oria], Politehnica University of Timisoara, Management Faculty, 14 Remus str, 300191 Timisoara, Romania, mizvercianu@mpt.upt.ro,mmocan@expertconsulting.ro,hpopa@eng.upt.ro

This Publication has to be referred as: Izvercianu, M.; Mocan, M. \& Popa, H. (2007). Training need for Business Creation in Automation Field, Chapter 31 in DAAAM International Scientific Book 2007, B. Katalinic (Ed.), Published by DAAAM International, ISBN 3-901509-60-7, ISSN 1726-9687, Vienna, Austria DOI: $10.2507 /$ daaam.scibook.2007.31 